\title{
SUSTAINABLE ALKALINE MEMBRANE FUEL CELL
}

\author{
R. C. Raimundo , \\ J. V. C. Vargas \\ W. Balmant ${ }^{a}$, \\ J. C. Ordonez ${ }^{\text {, }}$ \\ and S. Yang \\ ${ }^{A}$ sustainable Energy R\&D Center, \\ Federal University Of Paraná \\ Cp. 19011, Curitiba, Paraná, Brazil \\ Jvargas@Demec.Ufpr.Br \\ ${ }^{B}$ center For Advanced Power Systems \\ Department Of Mechanical Engineering \\ Tallahassee, Fl 32310, Usa \\ ABSTRACT \\ This work proposes a sustainable alkaline membrane fuel cell (SAMFC) \\ comprising a traditional AMFC coupled to a hydrogen generation reactor. \\ The reactor uses recycled aluminum from soda cans to split the water \\ molecule via oxidation catalyzed by $\mathrm{NaOH}$, and an innovative cellulose \\ membrane eliminates the undesirable characteristics of liquid electrolytes and \\ asbestos or ammonia---common constituents of alkaline electrolyte \\ membranes that are toxic and carcinogenic. Oxygen is supplied to the cell by \\ first directing the ambient air through $\mathrm{KOH}$ aqueous solution to remove $\mathrm{CO}_{2}$ \\ and thus to avoid the formation of $\mathrm{K}_{2} \mathrm{CO}_{3}$. In this paper, an SAMFC system \\ with one unitary cell, reactor, and $\mathrm{CO}_{2}$ purifier was designed, built, and tested \\ in the laboratory, and the system was compared experimentally against \\ traditional AMFCs driven by commercial hydrogen and by the hydrogen \\ derived from commercial aluminum. According to experimental polarization \\ and power curves, the SAMFC delivered $0.9 \mathrm{~V}$ in open circuit and \\ approximately $0.42 \mathrm{~W}$ of maximum power with recycled aluminum. The \\ study thereby demonstrates the economic potential and competitive \\ performance of the proposed SAMFC against traditional fuel cells. \\ Received: December 10, 2019 \\ Revised: February 20, 2020 \\ Accepted: March 25, 2020 \\ Keywords: alkaline membrane; aluminum; fuel cell; sustainability
}

\section{NOMENCLATURE}

$\begin{array}{ll}\mathrm{B}_{\mathrm{i}} & \text { bias limit of quantity } \mathrm{i} \\ \mathrm{I} & \text { current, } \mathrm{A} \\ \mathrm{P} & \text { power, } \mathrm{m} \\ \mathrm{P}_{\mathrm{i}} & \text { precision limit of quantity } \mathrm{i} \\ \mathrm{U}_{\mathrm{i}} & \text { uncertainty limit of quantity } \mathrm{i} \\ \mathrm{V} & \text { voltage, } \mathrm{V}\end{array}$

\section{Subscripts}

$\begin{array}{ll}\text { g } & \text { gas } \\ \mathrm{l} & \text { liquid } \\ \mathrm{s} & \text { solid }\end{array}$

\section{INTRODUCTION}

Fuel cell technologies have emerged as prominent alternatives to traditional coal-based power plants as they leverage electrochemical reaction which is highly efficient, simple, silent, and yields nonhazardous byproducts. Machado et al. (2018) highlight, for example, the applications of fuel cells as power generators in space stations and satellites as well as how the technological advancements have further extended their use cases over the past years. Fuel cells are typically classified by their electrolyte type, and the representative ones are alkaline fuel cell (AFC), proton exchange membrane fuel cell (PEMFC), phosphoric acid fuel cell (PAFC), molten carbonate fuel cell (MCFC), and solid oxide fuel cell (SOFC).

According to Mclean et al. 2002, AFCs were the first commercialized fuel cells to generate electricity from hydrogen. The main drawbacks of AFCs, however, are the use of liquid electrolytes, highly reactive potassium hydroxide $\mathrm{KOH}$ solution to carbon dioxide $\left(\mathrm{CO}_{2}\right)$ (Merle and Nijmeijer, 2011), and high cost. PEMFCs hence became an attractive alternative particularly for vehicles, but it also posed challenges such as water management and high cost of platinum and Nafion membrane (Ebrahimi et al., 2017). To overcome the limitations persisting in alkaline and PEM fuel cells, a new fuel cell type with anionic exchange membrane, also known as alkaline membrane fuel cell (AMFC), was developed. Although the technology is still nascent, its enormous potential as the next generation fuel cell has already drawn extensive research interests (Henkensmeier et al., 2017).

Ongoing investigations of AMFCs focus primarily on two aspects---development of highperformance ionic membranes and use of abundant electrode catalysts (Hou et al., 2017). The anionic exchange membrane has been developed to solve the problems with liquid electrolyte in AFCs while its resistance to corrosion yields high durability. Furthermore, the membrane facilitates the kinetics for oxygen reduction reaction which makes it favorable over PEMFCs for power generation (Alesker et al., 2016; Dekel, 2018). Despite its advantages, AMFC technology also needs to overcome the challenges related to anionic membrane material selection and hydrogen production. Typical anion-exchange membrane cells, for instance, feature asbestos separator saturated in potassium hydroxide or solid 
anionic membranes like ammonia-based alkaline membranes to eliminate carbon dioxide poisoning, but ammonia is toxic and flammable while asbestos is a known carcinogenic agent.

This study addresses the aforementioned limitations of AMFCs by proposing a sustainable AMFC characterized by the following: (1) nontoxic and nonflammable cellulose membranes and (2) driven by the hydrogen obtained from recycled aluminum. Furthermore, we discuss herein the potential use of cellulose membranes as a viable and beneficial alternative to conventional membranes as not enough information on this new technology is available in the literature. The proposed concept is illustrated in Figure 1 where hydrogen is derived from residual (recycled) aluminum which is then supplied to an AMFC along with oxygen from ambient air to provide electricity. During this process, aluminum is recovered and recycled for additional hydrogen production.

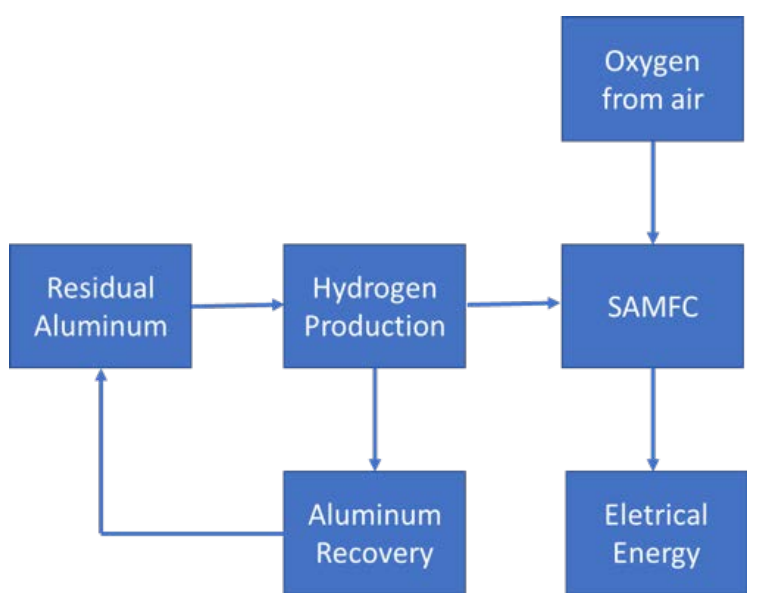

Figure 1. Sustainable AMFC flowchart.

\section{HYDROGEN PRODUCTION}

Most fuel cells use hydrogen as fuel and there exist several hydrogen synthesis technologies. The most common one is a fossil fuel-based process called steam reforming of methane (SRM). Steam reforming is a highly endothermic process and requires an effective way of supplying heat to the reactor (see Mundhwa and Thurgood (2017)for example) as the process takes place at temperatures between $700^{\circ} \mathrm{C}-900^{\circ} \mathrm{C}$. In addition, a large amount of water vapor is used to promote the exothermic reaction in the shift reactor (Baysal et al., 2017). The major drawback of this approach is the amount of $\mathrm{CO}_{2}$ emitted during reaction aside from the methane derived from fossil fuels. As a result, scientists and engineers have highlighted the need for clean and sustainable hydrogen production methods (Kothari et al., 2008).

Perhaps one of the most widely-adopted hydrogen production method is electrolysis. The electricity cost associated with the operation of electrolyzers has limited their use at large scale. More recent investigations on effective hydrogen production methods include the use of metals. Aluminum and its alloys, for example, have mechanical, electrical, and thermal properties suitable for hydrogen production.

Aluminum is the most abundant metal in the earth's crust, and it is easily found in soda cans, although elemental aluminum is not found free in nature (only as part of compounds) and there are negative environment consequences of mining and processing. Recycling aluminum is therefore beneficial for the environment, and further advantages emerge when combined with hydrogen. Aluminum hydroxide, for instance, can be recycled for a continuous fuel cell operation, and the reaction byproduct $\mathrm{AlOH}_{3}$ can be used to produce other aluminum salts, in pharmaceuticals (hydroxides), or in electrolysis. The reaction is catalyzed by sodium or potassium hydroxides which can also be fully recovered (Momirlan and Veziroglu, 2002; Soler et al., 2009;Porciuncula et al., 2012). Another advantage of aluminum is its relatively low density compared to other metals, and such a characteristic can significantly reduce the overall system mass (Rosenband et al., 2010; Huang et al., 2013).

Despite its advantages, a passive oxide film in metallic aluminum may impede the reaction from occurring, and novel techniques that use sodium or potassium hydroxide as catalysts have been proposed to trigger reactions. Alkaline catalysts dissolve the oxide and expose the aluminum surface to react with water (Soler et al., 2007; Froes et al., 2009). According to Soler et al. (2007), one advantage of using sodium or potassium hydroxide as catalysts is that reactions can take place in mild operating conditions as follows:

$$
\mathrm{Al}(\mathrm{s})+3 \mathrm{H}_{2} \mathrm{O}(\mathrm{l}) \stackrel{\mathrm{NaOH}(\mathrm{s})}{\longrightarrow} \mathrm{Al}(\mathrm{OH})_{3}(\mathrm{~s})+\frac{3}{2} \mathrm{H}_{2}(\mathrm{~g})
$$

\section{EXPERIMENT SETUP}

The experimental fuel cell configuration consists of two brass plates for reactants (one for $\mathrm{H}_{2}$ and another for $\mathrm{O}_{2}$ ), each with a side area of 144 $\mathrm{cm}^{2}$ and $1 \mathrm{~cm}$ thick and parallel channels for gaseous flow (see Figure 2). In addition, there are two platinum electrodes, for cathode and anode, and an anionic cellulose membrane saturated with $\mathrm{KOH}$ $(40 \backslash \% \mathrm{w} / \mathrm{w})$ placed in between the electrodes. The membrane is composed of a filter paper of special composition for proper electrolyte absorption and durability, providing a novel and inexpensive method of introducing the potassium hydroxide electrolyte to the cell. An acrylic support holds the AMFC assembly as seen in Figure 3 and there is no need to keep the cell suspended nor insulated to avoid contact between the metal parts. 


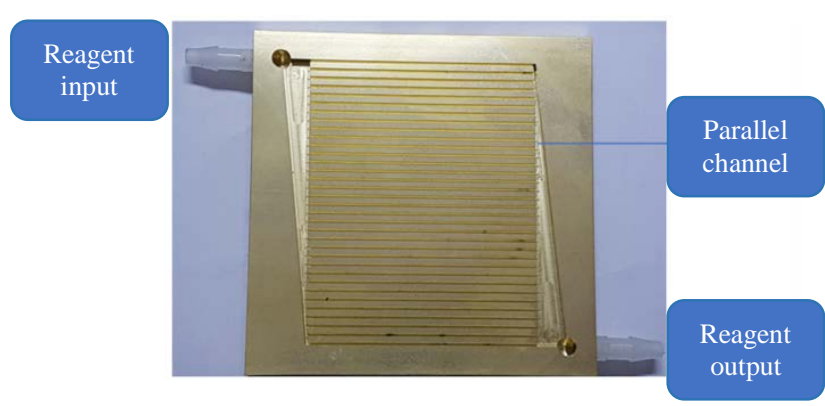

Figure 2. Fuel cell brass plate.
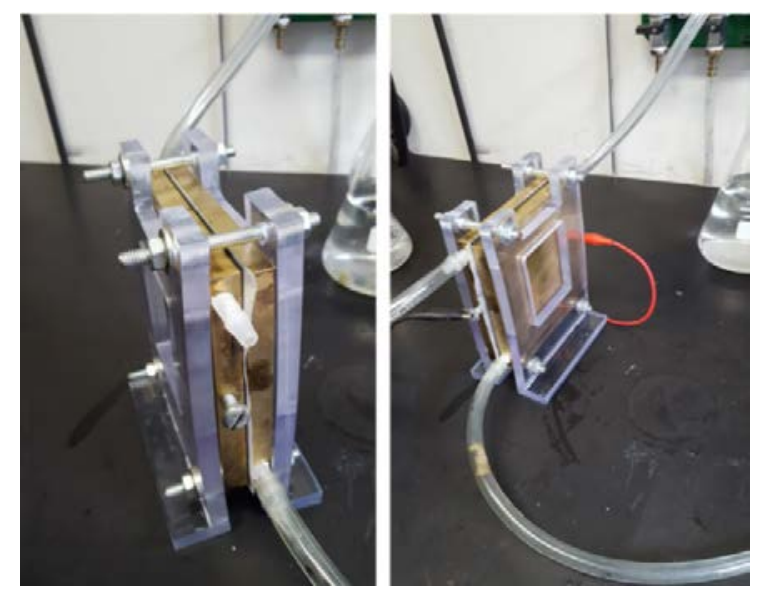

Figure 3. Fuel cell assembly.

The experiment was carried out with commercial hydrogen (99.5\\%) and with hydrogen from recycled aluminum. Hydrogen was produced via hydrolysis with aluminum using potassium hydroxide as a catalyst $(1.5 \mathrm{M})$. Both commercial and residual aluminum shown in Figure 4 were used to produce hydrogen for comparison purposes. The recycled aluminum came from soda cans which were triturated with a TRF 300G fodder crusher to increase the contact area of aluminum with the aqueous solution and to promote reaction kinetics. The unit cell was fed with hydrogen from aluminum in the presence of the catalyst (for commercial and recycled) which took place in a Kitasato reactor. Oxygen was obtained from ambient air, which passed through an aqueous solution of $\mathrm{KOH}(20 \backslash \% \mathrm{w} / \mathrm{w})$ in an Erlenmeyer to remove $\mathrm{CO}_{2}$ and to avoid the formation of $\mathrm{K}_{2} \mathrm{CO}_{3}$ and was supplied by a compressor.

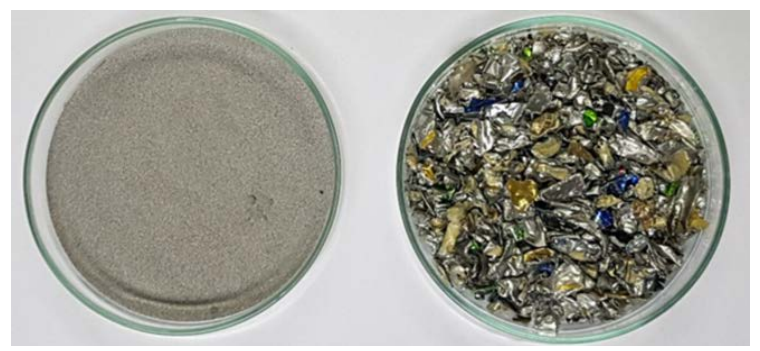

Figure 4. Commercial and residual aluminum compared in the experiment.
Each test consisted of measuring the current and voltage to quantify the performance based on the polarization curves. The resistance was imposed by a nickel-chrome wire that was connected to the system to vary the electrical load between the maximum and minimum limits, from the open circuit $(I=0)$ to short circuit conditions. The voltage and current precision limits for each experiment were computed as two times the standard deviation of the 3 runs (Kim et al., 1993), and it was assumed that the system response followed a symmetric unimodal normal distribution. Subsequently, 95\\% of the system responses exhibited actual voltage and current equal to the calculated mean (from the sample measurements) with twice the experimental standard deviation (Van Belle, 2011). Both the voltage and current bias limits were negligible in the presence of respective precision limits. Due to the low current range observed in the SAMFC stack prototype $\left(0 \leq \mathrm{I} \leq \mathrm{I}_{\max }\right)$, pumping power was neglected and therefore $\mathrm{P}_{\text {net }} \approx \mathrm{P}=\mathrm{VI}$. As a result, the measurement uncertainties were obtained from the following equation:

$$
\frac{\mathrm{U}_{\mathrm{i}}}{\mathrm{i}}=\left[\left(\frac{\mathrm{B}_{\mathrm{i}}}{\mathrm{i}}\right)^{2}+\left(\frac{\mathrm{P}_{\mathrm{i}}}{\mathrm{i}}\right)^{2}\right]^{1 / 2} \cong \frac{\mathrm{P}_{\mathrm{i}}}{\mathrm{i}}
$$

where $\mathrm{I}=\mathrm{V}$, I, or $\mathrm{P}$.

\section{RESULTS AND DISCUSSION}

The results for a single-cell AMFC with commercial hydrogen are show in Figure 5 and Table 1. The open-circuit voltage was $0.95 \mathrm{~V}$, and while the thermodynamic fuel cell voltage at $25^{\circ} \mathrm{C}$ is $1.23 \mathrm{~V}$, the fuel cell voltage was approximately $0.90 \mathrm{~V}$ under the operating conditions considered herein. Furthermore, the maximum power obtained in the experiment was $0.42 \mathrm{~W}$.

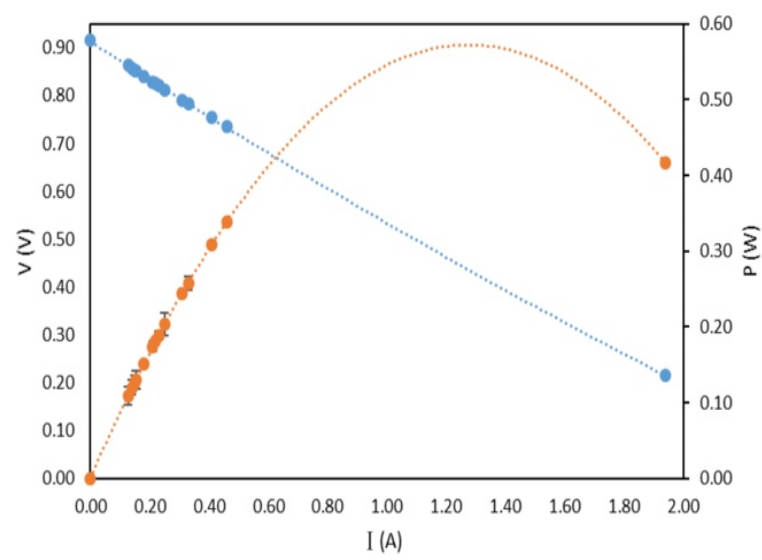

Figure 5. Polarization curve for commercial hydrogen-AMFC.

Table 1. Commercial hydrogen-AMFC experiment 


\begin{tabular}{cccccc} 
data. & \multicolumn{1}{c}{} \\
\hline $\mathrm{I}(\mathrm{A})$ & $\mathrm{V}(\mathrm{V})$ & $\mathrm{P}(\mathrm{W})$ & $U_{I} / I$ & $U_{V} / V$ & $U_{P} / P$ \\
\hline 0.000 & 0.916 & 0.000 & 0.000 & 0.001 & 0.001 \\
1.940 & 0.215 & 0.417 & 0.000 & 0.000 & 0.000 \\
0.460 & 0.735 & 0.338 & 0.000 & 0.002 & 0.003 \\
0.410 & 0.754 & 0.309 & 0.000 & 0.002 & 0.004 \\
0.330 & 0.782 & 0.258 & 0.000 & 0.003 & 0.009 \\
0.310 & 0.790 & 0.245 & 0.000 & 0.001 & 0.005 \\
0.250 & 0.812 & 0.203 & 0.000 & 0.004 & 0.015 \\
0.230 & 0.822 & 0.189 & 0.000 & 0.001 & 0.006 \\
0.220 & 0.825 & 0.182 & 0.000 & 0.000 & 0.000 \\
0.210 & 0.828 & 0.174 & 0.000 & 0.001 & 0.007 \\
0.180 & 0.840 & 0.151 & 0.000 & 0.000 & 0.000 \\
0.153 & 0.852 & 0.131 & 0.088 & 0.002 & 0.119 \\
0.150 & 0.852 & 0.128 & 0.000 & 0.001 & 0.009 \\
0.140 & 0.857 & 0.120 & 0.000 & 0.001 & 0.010 \\
0.127 & 0.863 & 0.109 & 0.106 & 0.000 & 0.122 \\
\hline
\end{tabular}

The same experiment was conducted with hydrogen derived from commercial aluminum (i.e., commercial-SAMFC), and its results are listed in Figure 6 and Table 2 according to which the opencircuit voltage was $0.90 \mathrm{~V}$. This voltage was slightly lower than that of commercial hydrogen-AMFC and the power for a single-cell commercial-SAMFC was $0.39 \mathrm{~W}$, i.e., $9 \backslash \%$ reduction from the commercial hydrogen-AMFC.

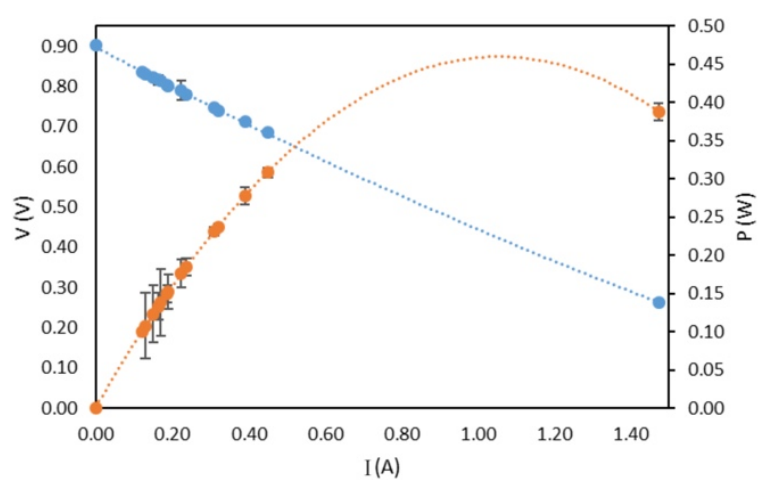

Figure 6. Polarization curve for commercial aluminum-SAMFC.

Table 2. Commercial aluminum-SAMFC experiment data.

\begin{tabular}{cccccc}
\hline $\mathrm{I}(\mathrm{A})$ & $\mathrm{V}(\mathrm{V})$ & $\mathrm{P}(\mathrm{W})$ & $U_{I} / I$ & $U_{V} / V$ & $U_{P} / P$ \\
\hline 0.000 & 0.903 & 0.000 & 0.000 & 0.001 & 0.001 \\
1.473 & 0.263 & 0.388 & 0.030 & 0.004 & 0.012 \\
0.450 & 0.685 & 0.308 & 0.000 & 0.003 & 0.006 \\
0.390 & 0.711 & 0.277 & 0.000 & 0.004 & 0.011 \\
0.320 & 0.740 & 0.237 & 0.000 & 0.002 & 0.005 \\
0.310 & 0.746 & 0.231 & 0.000 & 0.002 & 0.005 \\
0.237 & 0.779 & 0.184 & 0.063 & 0.008 & 0.011 \\
0.223 & 0.790 & 0.177 & 0.065 & 0.023 & 0.019 \\
0.190 & 0.802 & 0.152 & 0.000 & 0.004 & 0.023 \\
0.187 & 0.803 & 0.150 & 0.077 & 0.002 & 0.011 \\
0.163 & 0.816 & 0.133 & 0.087 & 0.012 & 0.018 \\
\hline
\end{tabular}

\begin{tabular}{llllll}
\hline 0.170 & 0.814 & 0.138 & 0.000 & 0.008 & 0.044 \\
0.150 & 0.821 & 0.123 & 0.000 & 0.006 & 0.037 \\
0.130 & 0.830 & 0.108 & 0.000 & 0.006 & 0.043 \\
0.120 & 0.835 & 0.100 & 0.000 & 0.003 & 0.002 \\
\hline
\end{tabular}

Figure 7 and Table 3 show polarization curve for hydrogen obtained from soda can aluminum, i.e., recycled aluminum-SAMFC. The open-circuit voltage was also $0.90 \mathrm{~V}$ as with the commercial aluminum, and the maximum power maximum was $0.35 \mathrm{~W}$, approximately $12.8 \backslash \%$ reduction from that obtained with commercial hydrogen. The following quadratic equations representing power as a function of current were obtained by fitting the experiment data, based on which the maximum power for each aforementioned test case was estimated:

$$
\begin{aligned}
& P=-0.3511 I^{2}+0.8956 I+0.0012 \\
& P=-0.4115 I^{2}+0.8683 I+0.0019 \\
& P=-0.3825 I^{2}+0.87858 I+0.0008
\end{aligned}
$$

The reported voltage, current, and power obtained experimentally are in the same order of magnitude as other works conducted under different conditions (Won et al., 2017; Dekel, 2018).

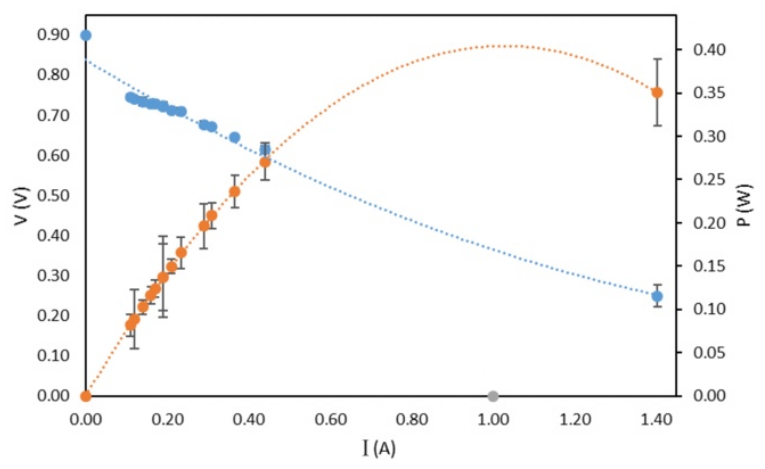

Figure 7. Polarization curve for recycled aluminumAMFC.

Table 3. Recycled aluminum-SAMFC experiment data.

\begin{tabular}{cccccc}
\hline $\mathrm{I}(\mathrm{A})$ & $\mathrm{V}(\mathrm{V})$ & $\mathrm{P}(\mathrm{W})$ & $U_{I} / I$ & $U_{V} / V$ & $U_{P} / P$ \\
\hline 0.000 & 0.916 & 0.000 & 0.000 & 0.001 & 0.001 \\
1.940 & 0.215 & 0.417 & 0.063 & 0.031 & 0.033 \\
0.460 & 0.735 & 0.338 & 0.000 & 0.008 & 0.017 \\
0.410 & 0.754 & 0.309 & 0.044 & 0.005 & 0.014 \\
0.330 & 0.782 & 0.258 & 0.000 & 0.004 & 0.012 \\
0.310 & 0.790 & 0.245 & 0.000 & 0.006 & 0.021 \\
0.250 & 0.812 & 0.203 & 0.065 & 0.009 & 0.015 \\
0.230 & 0.822 & 0.189 & 0.000 & 0.007 & 0.006 \\
0.220 & 0.825 & 0.182 & 0.000 & 0.006 & 0.029 \\
0.210 & 0.828 & 0.174 & 0.000 & 0.008 & 0.037 \\
0.180 & 0.840 & 0.151 & 0.000 & 0.007 & 0.008 \\
\hline
\end{tabular}




\begin{tabular}{llllll}
\hline 0.153 & 0.852 & 0.131 & 0.000 & 0.007 & 0.009 \\
0.150 & 0.852 & 0.128 & 0.000 & 0.009 & 0.006 \\
0.140 & 0.857 & 0.120 & 0.000 & 0.004 & 0.025 \\
0.127 & 0.863 & 0.109 & 0.000 & 0.006 & 0.009 \\
\hline
\end{tabular}

\section{CONCLUSION}

The proposed SAMFC prototype with a cellulose electrode was built, tested and compared against other AMFCs whose hydrogen came from commercial supplier or derived from commercial aluminum powder. The open-circuit voltage and peak power were $0.95 \mathrm{~V}$ and $0.42 \mathrm{~W}$ for commercial hydrogen-AMFC, $0.90 \mathrm{~V}$ and $0.39 \mathrm{~W}$ for commercial aluminum-SAMFC, and $0.90 \mathrm{~V}$ and $0.35 \mathrm{~W}$ for recycled aluminum-SAMFC. According to these results, the proposed system has a great potential for industrial use and the integration of a cellulose membrane as an electrolyte promotes cost reduction and clean power generation. Moreover, producing hydrogen from recycled aluminum is an attractive solution in a society where sustainability is eagerly sought, and this study verifies both the feasibility and potential of the proposed SAMFC as an effective alternative to existing fuel cells.

\section{ACKNOWLEDGEMENTS}

The authors acknowledge with gratitude the support from Brazilian National Council of Scientific and Technological Development, CNPq, CAPES (projects 200/2007 and 2424/11-8), and the Engineering and Materials Science Postgraduate Program at the Federal University of Paraná.

\section{REFERENCES}

Alesker, M., Page, M., Shviro, M., Paska, Y., Gershinsky, G., Dekel, D. R., and Zitoun, D., 2016, Palladium/Nickel Bifunctional Electrocatalyst for Hydrogen Oxidation Reaction in Alkaline Membrane Fuel Cell, Journal of Power Sources, Vol. 304, pp. 332-339.

Baysal, M., Gunay, M. E., and Yıldırım, R., 2017, Decision Tree Analysis of Past Publications on Catalytic Steam Reforming to Develop Heuristics for High Performance: A statistical Review, International Journal of Hydrogen Energy, Vol. 42, No. 1, pp. 243254.

Dekel, D. R., 2018, Review of cell performance in anion exchange membrane fuel cells. Journal of PowerSources, 375:158-169.

Ebrahimi, S., Ghorbani, B., and Vijayaraghavan, K., 2017, Optimization of Catalyst Distribution Along PEMFC Channel Through a Numerical Two-Phase Model and Genetic Algorithm. Renewable Energy, Vol. 113, pp. 846-854.

Froes, R. E., Neto, W. B., Naveira, R. L., Silva, N. C., Nascentes, C. C., and da Silva, J. B., 2009, Exploratory Analysis and Inductively Coupled
Plasma Optical Emission Spectrometry (ICPOES) Applied in the Determination of Metals in Soft Drinks, Microchemical Journal, Vol. 92, No. 1, pp. 68-72.

Henkensmeier, D., Dyck, A., Holdcroft, S., and Varcoe, J., 2017, Special Section on Anion Exchange Membranes and AEM-based Systems, Journal of Electrochemical Energy Conversion and Storage, Vol. 14, No. 2, pp. 020301.

Hou, J., Lei, Y., Wang, F., Ma, X., Min, S., Jin, Z., and $\mathrm{Xu}$, J., 2017, In-situ Photochemical Fabrication of Transition Metal-Promoted Amorphous Molybdenum Sulfide Catalysts for Enhanced Photosensitized Hydrogen Evolution, International Journal of Hydrogen Energy, Vol. 42, No. 16, pp. 11118-11129.

Huang, X., Gao, T., Pan, X., Wei, D., Lv, C., Qin, L., and Huang, Y., 2013, A Review: Feasibility of Hydrogen Generation from the Reaction between Aluminum and Water for Fuel Cell Applications, Journal of Power Sources, Vol. 229, pp. 133-140.

Kim, J. H., Simon, T. W., and Viskanta, R., 1993, Journal of Heat Transfer Policy on Reporting Uncertainties in Experimental Measurements and Results, Journal of Heat Transfer, Vol. 115, No. 1, pp. 5-6.

Kothari, R., Buddhi, D., and Sawhney, R., 2008, Comparison of Environmental and Economic Aspects of Various Hydrogen Production Methods, Renewable and Sustainable Energy Reviews, Vol. 12, No. 2, pp. 553-563.

Machado, B. S., Chakraborty, N., Mamlouk, M., and Das, P. K., 2018, A Three-Dimensional Agglomerate Model of an Anion Exchange Membrane Fuel Cell, Journal of Electrochemical Energy Conversion and Storage, Vol. 15, No. 1, pp. 011004.

McLean, G., Niet, T., Prince-Richard, S., and Djilali, N., 2002, An Assessment of Alkaline Fuel Cell Technology, International Journal of Hydrogen Energy, Vol. 27, No. 5, pp. 507-526.

Merle, G., Wessling, M., and Nijmeijer, K., 2011, Anion Exchange Membranes for Alkaline Fuel Cells: A Review, Journal of Membrane Science, Vol. 377, No. 1-2, pp. 1-35.

Momirlan, M. and Veziroglu, T., 2002, Current Status of Hydrogen Energy, Renewable and Sustainable Energy Reviews, Vol. 6, No. 1-2, pp. 141-179.

Mundhwa, M., and Thurgood, C. P., 2017, Numerical Study of Methane Steam Reforming and Methane Combustion over the Segmented and Continuously Coated Layers of Catalysts in a Plate Reactor, Fuel Processing Technology, Vol. 158, pp. 57-72.

Porciuncula, C., Marcilio, N., Tessaro, I., and Gerchmann, M., 2012, Production of Hydrogen in the Reaction between Aluminum and Water in the Presence of Naoh and Koh, Brazilian Journal of Chemical Engineering, Vol. 29, No. 2, pp. 337-348. 
Rosenband, V. and Gany, A., 2010, Application of Activated Aluminum Powder for Generation of Hydrogen from Wate, International Journal of Hydrogen Energy, Vol. 35, No. 20, pp. 10898-10904.

Soler, L., Candela, A. M., Macanas, J., Munoz, M., and Casado, J., 2009, In Situ Generation of Hydrogen from Water by Aluminum Corrosion in Solutions of Sodium Aluminate, Journal of Power Sources, Vol. 192, No. 1, pp. 21-26.

Soler, L., Macanas, J., Munoz, M., and Casado, J., 2007, Aluminum and Aluminum Alloys as Sources of Hydrogen for Fuel Cell Applications, Journal of Power Sources, Vol. 169, No. 1, pp. 144149.

Van Belle, G., 2011, Statistical Rules of Thumb, Vol. 699, John Wiley \& Sons.

Won, W., Kwon, H., Han, J.-H., and Kim, J., 2017, Design and Operation of Renewable Energy Sources Based Hydrogen Supply System: Technology Integration and Optimization, Renewable Energy, Vol. 103, pp. 226-238. 